\title{
45 Materiaal en verband
}

Bij een functioneel verband is hoogwaardig verbandmateriaal dat recht doet aan de indicatie net zo belangrijk als deskundige aanlegtechniek. Zonder goed verbandmateriaal zal een bandage, hoe perfect ook aangelegd, slechts een beperkt effect hebben. Gedetailleerde kennis van de verschillende materialen is daarom een voorwaarde voor het vakkundig gebruik ervan.

Een functioneel verband heeft twee essentiële doelstellingen:

- optimale actieve en passieve stabiliteit;

- optimale, doelgerichte mobiliteit.

Deze doelstellingen worden het best bereikt met een rechtstreeks op de huid geplakt verband. Door de hechting aan de huid wordt via mechano-en nociceptoren de voor de actieve stabilisatie noodzakelijke neuromusculaire reactie opgewekt. De optimale passieve stabiliteit wordt gegarandeerd wanneer gebruik wordt gemaakt van zo min mogelijk stevig op elkaar plakkende lagen tape. Elke laag beweegt zich licht ten opzichte van de andere, wat leidt tot een verlies van stabiliteit. Hoe meer lagen, hoe groter het verlies. Meerlaags verband is bovendien dikker en bemoeilijkt het aantrekken van schoenen. Doelgerichte mobiliteit kan worden verkregen door de techniek van het verbinden en door de verschillende materialen te combineren. De basismaterialen van het tapen of van de functionele verbandtechniek zijn de tapes of pleisterverbanden. Hieronder verstaan wij niet-elastisch of elastisch materiaal van verschillende lengte en breedte, voorzien van een zelfklevende laag.

Voor de kwalitatieve beoordeling van pleisterverbanden zijn de volgende criteria van belang: kleefkracht, stevigheid van het materiaal en huidverdraagzaamheid.

\section{Kleefkracht}

Directe, duurzame kleefkracht - ook onder extreme omstandigheden - is een belangrijk criterium. De benodigde kleefkracht is afhankelijk van de indicatie. Voor een bandage ter ontlasting van de achillespees waarbij grote trekkrachten kunnen optreden, is een zeer sterke hechting noodzakelijk, terwijl voor een circulair compressieverband een geringe hechting aan de huid volstaat.

\section{Stevigheid van het materiaal}

Voor niet-elastische tapes zijn stabiliteit, trekvastheid en handmatige scheurbaarheid de belangrijkste criteria. Een elastisch pleisterverband bestaat bijna volledig uit textielelastisch katoenweefsel. Het mag maar beperkt rekbaar zijn (30-60\%), weinig krimpkracht hebben, weinig vermoeidheidsverschijnselen (elasticiteitsverlies) vertonen en het moet trekvast zijn.

\section{Huidverdraagzaamheid}

Goede huidverdraagzaamheid en lucht- en waterdampdoorlatendheid zijn wezenlijke eigenschappen van een tape- of pleisterverband - vooral wanneer het verband voor een langere periode direct op de huid wordt geplakt of wanneer de verbanden vaak, in uitzonderlijke gevallen meermalen per dag, moeten worden verwisseld.

Bij een duurzaam verband en/of gevoelige huid is extra huidbescherming in de vorm van een onderlaag meestal noodzakelijk. Bovendien moeten tapes/pleisterverbanden aan de weefselkant water- en vuilafstotend geïmpregneerd zijn. 